\title{
EAST TIMOR'S LAND TENURE PROBLEMS: A CONSIDERATION OF LAND REFORM PROGRAMS IN SOUTH AFRICA AND ZIMBABWE
}

\author{
Amy Ochoa Carson*
}

\section{INTRODUCTION}

This Note suggests ways to alleviate East Timor's ${ }^{1}$ land tenure problems. These problems resulted from the country's complicated history. ${ }^{2}$ In 2002 , East Timor was given its long-awaited independence and became the world's newest nation. ${ }^{3}$ Since being discovered in the 1500 s, East Timor was originally a Portuguese colony ${ }^{4}$ and, more recently, an Indonesian colony. ${ }^{5}$ Now that East Timor has gained its independence, it faces many obstacles before it can become a successful, self-sufficient nation. As of 2005, the country had one of the lowest real gross domestic products (GDP) in the world at eight hundred dollars. ${ }^{6}$

A massive problem East Timor must overcome is its complicated and

* J.D. Candidate, Indiana University School of Law-Indianapolis, 2007. B.A., Hanover College, 2004.

1. In this Note the name East Timor will be used. There are, however, various names for the country of East Timor:

The name most common in the English-speaking West is really a tautology since Timor is just the Indonesian word for 'east'. So East Timor is East East, and in fact the Indonesians referred to the province as Timor Timur or, in its shortened version, Tim Tim. ... .

. . . [East Timor is also called] Timor Leste, which is East Timor in Portuguese. Or Timor Lorosae (also Loro Sa'e and Lor Sae), which can be Translated as 'Timor where the sun rises' in Tetun. Finally, the official English language name is Democratic Republic of East Timor ....

TONY WHEELER, EAST TIMOR 33 (2004).

2. Daniel Fitzpatrick, Property Rights in East Timor's Reconstruction and Development, in EAST TIMOR DEVELOPMENT ChalleNGES FOR THE WORLD's NEWEST NATION 178 (Hal Hill \& João M. Saldanha eds., 2001).

3. See id. at 177.

4. Herbert D. Bowman, Letting the Big Fish Get Away: The United Nations Justice Effort in East Timor, 18 EMORY INT'L L. REV. 371, 373 (2004).

5. Id. at 375 .

6. Central Intelligence Agency, Rank Order-GDP - per capita (PPP), in THE WORLD FACTBOOK (2007). GDP is "the total value of goods and services produced in a country over a period of time." MSN Encarta, Gross Domestic Product, http://encarta.msn.com/encyclopedia_761588125/Gross_Domestic_Product.html (last visited February 25, 2007). There are three ways to calculate GDP: "(1) by adding up the value of all goods and services produced, (2) by adding up the expenditure on goods and services at the time of sale, or (3) by adding up producers' incomes from the sale of goods or services." $1 d$. GDP is used by economists "to measure the standard of living in a country. They divide a country's GDP by its population to arrive at GDP per head." Id. 
extensive land tenure issues, ${ }^{7}$ Because the country went from being a territory of one state to the territory of another, it faces a number of conflicting land title problems. $^{8}$ The violent military conflict that occurred directly prior to the country's independence exacerbated the problem. ${ }^{9}$ This period of violence, brought about by the Indonesian military, resulted in the destruction of the country's infrastructure, buildings, and titles to land, leaving a legal disaster with regard to land tenure issues. ${ }^{10}$ The lack of certainty over land title and the damage done by the Indonesian military has seriously halted the country's ability to thrive economically. ${ }^{11}$ Thus, East Timor is in dire need of laws to determine ownership of land and new, progressive forms of land reform. Yet despite the exigency of the circumstances, careful thought and analysis must occur before determining the appropriate regulations in order to ensure land reform that is successful and withstands the test of time. ${ }^{12}$

There are four categories of land claims that the people of East Timor are bringing in hopes of reclaiming their land. ${ }^{13}$ This Note assesses the prospects for success of these various land claims and provides a comparative analysis to land reform that occurred in South Africa post-apartheid and Zimbabwe postcolonialism. Based upon these findings, this Note analyzes the mechanisms by which East Timor should work toward resolving its land tenure issues.

Part I discusses East Timor's colonial history. It begins with a discussion focusing on East Timor as a colony of Portugal. It then proceeds to examine East Timor as a colony of Indonesia. Lastly, Part II discusses the Referendum and the violence and destruction that occurred prior to the vote for independence and after the vote was announced.

Part II examines the unique situation in East Timor. Not only is the country facing problems associated with post-colonization, but it is also facing problems associated with a post-conflict environment. This Part then presents the four types of land claims that East Timor citizens are bringing in their independent country. The basis of each land claim is explained, as well as the problems of recognizing or ignoring such claims. True life accounts of the

7. See generally DANIEL FITZPATRICK, LAND ClaIMS In EAST TIMOR (2002). Land tenure is the "way people 'hold' rights to land and real property." HENRI A.L. DEKKER, THE INVISIBLE LINE: LAND REFORM, LAND TENURE SECURITY AND LAND REGISTRATION 43 (2003). Land tenure denotes both a "legal term" and an "emotional term." Id. The "emotional significance of land tenure [is] the way individuals perceive benefits, enjoyment, and obligations in respect to real property." Id.

8. See FITZPATRICK, supra note 7 , at 1.

9. See id. at 6 . During this time, many of the country's land records were intentionally destroyed. Id. at 7 .

10. See generally id. at 6-7 (finding that there are conflicting land titles and many people do not have proof that they own their land).

11. See Fitzpatrick, supra note 2, at 177-78.

12. See generally FITZPATRICK, supra note 7. See also DANIEL FITZPATRICK, COMMONWEALTH OF AUSTL., LAND ISSUES IN A NEWLY INDEPENDENT EAST TIMOR, Parliament of Australia (2001), http://www.aph.gov.au/library/pubs/rp/2000-01/01RP21.pdf.

13. See infra note 70 and accompanying text. 
difficult situations facing people in East Timor are then discussed in an effort to humanize this situation. This will allow readers to better understand the magnitude of problems facing the new East Timor government and its citizens. This part concludes with a discussion of the impact that land issues are having on East Timor to show why land tenure problems need to be resolved before the country can prosper.

Part III provides general information about land reform, specifically the benefits and detriments associated with such measures. The motives and reasons a country might choose to reform land ownership are also discussed. In addition, general criticisms against land reform are presented.

Part IV provides background information on South Africa, specifically the country's history regarding property rights and the ways in which South Africans were dispossessed of their land. The discussion then moves to events that took place post-apartheid with relation to land reform. The successes of the South African land reform program are presented, as well as the problems and shortcomings of the country's efforts to reform the land issues and distribute ownership interests more equally.

Part V explores Zimbabwe's colonial past and the impact it had on ownership of land. It then discusses the land reform program implemented following the country's independence. The country's attempted methods to reform the land to allow for more equal distribution among individuals are provided. Additionally, criticisms of Zimbabwe's efforts in reforming property rights are explained.

Part VI discusses recent developments in East Timor in the area of land tenure and its attempts to resolve land problems. This section presents recently enacted land laws. Additionally, Part VII provides an explanation of new departments and organizations dealing with land tenure.

Part VII provides suggestions of ways for East Timor to reform land use and begin to resolve conflicting land titles. This Note suggests that land reform is a good option for the country because it will provide land to landless individuals, redistribute land in a more equal manner than has been done in the past, and allow the country to improve economically by encouraging people to use the land productively. In making this argument, the failures and successes of land reform in South Africa and Zimbabwe will be evaluated and applied to East Timor in an effort to make predictions of problems that East Timor is likely to encounter in the future. This comparative analysis of land reform in South Africa and Zimbabwe will provide the groundwork for suggested methods to implement land reform in East Timor. 


\section{BACKGROUND INFORMATION AND HISTORY}

East Timor, a small country slightly larger than Connecticut, is located in southeastern Asia. ${ }^{14}$ The country has mountainous terrain and natural resources that include gold, petroleum, natural gas, manganese, and marble. ${ }^{15}$ Rice and maize are the country's "chief food crops." cashews, cloves, sugar, sandlewood, cocoa, and arabica coffee. ${ }^{17}$ Additionally, cattle and fishing are important activities for the country. ${ }^{18}$

Little is known about the early years of the island of Timor, however, it is believed the island was first visited by Chinese and Japanese traders as early as the seventh century. ${ }^{19}$ By 1513 Portuguese explorers arrived in Timor. ${ }^{20}$ Prior to the arrival of Portuguese explorers, Timor was "divided into a number of small kingdoms." 21 Next, the Dutch arrived. ${ }^{22}$ By 1858, a border arrangement commenced between the Portuguese and the Dutch. ${ }^{23}$ The arrangement essentially divided the island of Timor into East Timor and West Timor. ${ }^{24}$ East Timor became a Portuguese colony and West Timor became a Dutch colony. ${ }^{25}$ West Timor received its independence in 1949, and thereafter became part of the Indonesian Republic. ${ }^{26}$ Portuguese rule continued over East Timor until $1974 .^{27}$

In 1974, Portugal's dictator, Marcello Caetano, was overthrown. ${ }^{28}$ Subsequently, Portugal "quickly began divesting [itself] of its colonies."29 The East Timorese, realizing they were likely to be abandoned, formed groups to determine how the small country should gain independence. ${ }^{30}$ Indonesia, which

14. Central Intelligence Agency, CIA - The World Factbook -- East Timor, https://www.cia.gov:443/cia/publications/factbook/geos/tt.html (last visited Apr. 5, 2007).

15. Id.

16. WHEELER, supra note 1 , at 32 .

17. Id.

18. Id.

19. Id. at 20.

20. Bowman, supra note 4, at 373.

21. WHEELER, supra note 1 , at 20 . There was frequent conflict among the small kingdoms and "head hunting [was] a popular activity." Id.

22. JoSE RAMOS-HORTA, FUNU THE UNFINISHEd SAGA OF EAST TMMOR 19 (1987); see also Geoffrey C. Gunn, The Five-Hundred-Year Timorese Funu, in BITTER FLOWERS, SWEET FLOWERS EAST TIMOR, INDONESIA, AND THE WORLD COMMUNITY 5 (Richard Tanter et. al. eds., 2001).

23. Bowman, supra note 4 , at 374.

24. Id. The agreement, dividing the island into East Timor and West Timor, was not ratified until the year 1913. Id.

25. See id.

26. Id.

27. Id. There was a brief period of "Japanese occupation during World War II." Id.

28. Don Greenlees \& Robert Garran, Deliverance The Inside Story of East TIMOR's FIGHT FOR FREEDOM 4 (2002). Portugal was overthrown by Portuguese army officers in an effort to rid the country and "its oversea territories" of a repressive government. Id.

29. Bowman, supra note 4, at 374.

30. Id. The people of East Timor are called East Timorese. See generally id. The three 
occupied West Timor, feared an independent East Timor would threaten its security. ${ }^{31}$ In response to this fear, Indonesia "funneled support to individuals and parties willing to [push for] integration with Indonesia., 32

Ultimately, a civil war ensued between parties in favor of independence and parties in favor of integrating with Indonesia. ${ }^{33}$ Those supporting independence for East Timor were ultimately victorious but, despite this victory, the Indonesian troops still invaded East Timor. ${ }^{34}$ During the invasion, thousands of East Timorese were killed by the Indonesian military. ${ }^{35}$

In 1976, Indonesia declared East Timor to be its twenty-seventh province. ${ }^{36}$ Indonesia tried to "gain popular support" by fixing the country's infrastructure, schools, and hospitals, but at the same time continued to harass and murder East Timorese who opposed them. ${ }^{37}$ Despite the improvements made to the country, most East Timorese did not reap the benefits and their living standards did not improve. ${ }^{38}$ Instead, the estimated 150,000 non-East Timorese who lived in East Timor were the ones who primarily benefited from Indonesia's improvements and who held lucrative jobs in the country. "At no stage did the vast majority of the East Timorese people ever feel that they lived in [a place] other than an occupied territory." 40 By 1980, an estimated one-third

main political groups included the Timorese Democratic Union (UDT), the Timorese Social Democratic Party (ASDT), and the Timorese Popular Democratic Association (APODETI). See GREENLEES \& GARRAN, supra note 28, at 4. The UDT and ASDT both "advocated eventual independence"; however, the UDT proposed continuing an association with Portugal, whereas the ASDT completely rejected colonialism. Id. The APODETI initially had few followers but gained strength due to Indonesian intervention; it "supported integration with Indonesia." Id.

31. Bowman, supra note 4 , at 374 .

32. Id. at 374-75.

33. Id. at 375 .

34. Id. Don Greenlees, a correspondent for Australian in Jakarta, and Robert Garran, a long-time writer for major Australian newspapers in the areas of politics and economics, found that the United States "supported the invasion in spite of some misgivings, viewing the issue as one primarily for Indonesia, Portugal and Australia to resolve." GREENLEES \& GARRAN, supra note 28 , at 13 . See also RAMOS-HORTA, supra note 22 , at 1.

35. Bowman, supra note 4 , at 375 . Those who were not killed by the Indonesian military were forced into the mountainous regions of the country if they resisted Indonesian rule. Id.

36. GREENLEES \& GARRAN, supra note 28, at 15 . Within ten days of invading East Timor, Indonesia created an interim government in Dili. Id. Approximately five months later, Indonesia hand-picked thirty-seven delegates to appoint to the People's Assembly; subsequently, the Assembly voted to integrate with Indonesia. See id. at 11-15.

37. Bowman, supra note 4, at 375. "[T] he Indonesian security forces eroded [any support gained] by raping, torturing, murdering, and starving large portions of the population...." Id. Also note that "[e]ven the roads that Indonesia built in East Timor, of which it was unduly proud, served in large part to transport troops and equipment from district to district" and, thus, were not for the benefit of the people of East Timor. DAMIEN KingSBURY, SOUTH-EAST ASIA A POLITICAL PROFILE 397 (2001).

38. KINGSBURY, supra note 37 , at 397.

39. Id. The "East Timorese people were regarded as less than human by their new Indonesian masters." Id.

40. Id. During the Indonesian occupation of East Timor "[j] ournalists were usually forbidden entry to the territory." JOHN STACKHOUSE, OUT OF POVERTY AND INTO SOMETHING MORE COMFORTABLE 316 (2000). Journalist John Stackhouse, along with another journalist, 
of the country, approximately 200,000 East Timorese, were killed by the Indonesian military. ${ }^{41}$

In 1999, "Indonesian President B.J. Habibie surprised the world by announcing his intention to allow the East Timorese to choose between some type of autonomy within Indonesia and independence." ${ }^{, 42}$ In response to Habibie's announcement, Indonesia, Portugal, and the United Nations came to an agreement known as the Tripartite Agreement; it "allowed for a popular referendum in which the East Timorese would be allowed to vote for special autonomy within Indonesia or for a separation from Indonesia that would ultimately result in independence."43 The agreement stipulated that the United Nations would "conduct and monitor the referendum," and Indonesia was given the responsibility of providing security during the referendum period. ${ }^{44}$ The United Nations and Portugal agreed to allow Indonesia to provide security only after Indonesia insisted that "no U.N. peacekeepers be sent to East Timor" and that only a small amount of civilian police advisers be present. ${ }^{45}$

Despite the Indonesian military's efforts to keep the East Timorese people from voting, approximately $98.6 \%$ of the citizens ${ }^{46}$ voted on August 30, 1999. ${ }^{47}$ The result of the Referendum, announced on September $4,1999,{ }^{48}$ produced an outcome of $78.5 \%$ of East Timorese voting for their independence. ${ }^{49}$ This angered the Indonesian military; within hours after the vote was announced, "they began taking retribution on the people of East Timor and the island itself.",50

As a result of the militia violence, thousands of East Timorese were murdered and "over 450,000 people were estimated to have been internally displaced within East Timor itself, and a further 300,000 fled or were forcibly

snuck into East Timor and posed as tourists. Id. He found that there were more "police ... than civilians" to ensure that East Timorese did not speak to foreigners about politics or their dislike of Indonesia. Id. at 320. The police and government informants were everywhere: a "local school teacher ... discovered one of her ten-year-old pupils was a government informer." Id. at 327.

41. Bowman, supra note 4 , at 375 . The Indonesian army acted "like an insensitive occupying force" instead of "protectors of the peace." KINGSBURY, supra note 37, at 397.

42. Bowman, supra note 4 , at 375-76.

43. Id. at 376 .

44. Id.

45. GREENLEES \& GARRAN, supra note 28 , at 147 . The United Nations and Portugal faced the tough decision of either allowing the Referendum on Indonesia's terms or fighting Indonesia's terms and risk Habibie withdrawing his offer to allow the people of East Timor to vote on their future. Id. Ultimately, the United Nations and Portugal chose to agree to Indonesia's insistence that it provide security. See id.

46. Bowman, supra note 4, at 377. "The Indonesian military and much of the civilian leadership opposed President Habibie's initiative." Id. at 376. The military's objective was to cancel the vote. $I d$. In the alternative, the military hoped to influence, through intimidation and violence, East Timorese to vote against autonomy with Indonesia. Id.

47. GREENLEES \& GARRAN, supra note 28, at 191.

48. Id. at 202 .

49. Bowman, supra note 4 , at 377 .

50. Id. 
transported across the border to West Timor." $" 51$ The majority of government experts and administration fled the country "[b]ecause they were either nonEast Timorese or were pro-autonomy supporters." included all of the country's judges and most of the country's attorneys. ${ }^{53}$

East Timor was officially declared an independent nation on May 20 , $2002 .^{54}$ Nevertheless, this independence has not come without problems. ${ }^{55}$ The atrocities that occurred after the Referendum have left East Timor in a dire state. $^{56}$ Specifically, the country has had to deal with problems with land tenure. ${ }^{57}$ Many of the country's land records were destroyed during the period of violence after the Referendum. ${ }^{58}$ The Indonesian military purposely "entered the land titles building, took the records outside, set fire to them, and then torched the building itself." East Timor were destroyed. ${ }^{60}$ In addition, homes were intentionally burned and destroyed by the Indonesian military. ${ }^{61}$

The acts of the Indonesian military left the country with housing shortages and little evidence to ascertain ownership of parcels of land. ${ }^{62}$ This situation worsened when large numbers of people returned to East Timor under the force of the West Timor authorities. ${ }^{63}$ These people returned to East Timor to find their land occupied by other people or destroyed. ${ }^{64}$ The lack of

51. FITZPATRICK, supra note 7 , at 5.

52. Id. at 6.

53. Id.

54. Central Intelligence Agency, supra note 14.

55. See generally FITZPATRICK, supra note 7 (explaining the problems with the state of land tenure).

56. See id. at 6.

57. Id.

58. Id. at 7. In a positive occurrence, "a land professional who reportedly could not condone the destruction of records," took the Dili land titles book for safekeeping. Id. The book only contained evidence of registration and not any authorization or history. Id. The problem is that Indonesia has refused to return the book. Id.

59. Id. at 6. Kosovo, Iraq, Afghanistan, and Somalia are other cases in which "land ownership documents were taken, sometimes for 'ransom', sometimes for safety and sometimes to be destroyed." Daniel Lewis, UNHABITAT, Challenges to Sustainable PEACE: LAND DISPUTES FOLLOWNG CONFLICT http://www.fig.net/commission7/geneva_2004/papers/lapca_01_lewis.pdf (2004).

60. FITZPATRICK, supra note 7, at 7. Because of the extreme violence that occurred after the Referendum, the urgency to flee, and the forced departures, most people did not take their land titles when they left their homes. Id.

61. Id. at 8. "In Dili ... a milk truck was used to pump [gas] into houses before they were lit and destroyed." Id. In addition to homes and records, the Indonesian military also targeted infrastructure. Id. Reports from the United Nations Transitional Authority in East Timor (UNTAET) estimate that over ninety-five percent of the infrastructure in Dili was destroyed and a total of 70 per cent of the country's entire infrastructure was "destroyed or rendered inoperable." Id.

62. See id. at 6-17.

63. Id. at 9.

64. Id. This is not necessarily something new for rural areas of East Timor, but it has created a serious problem for large cities, like the capital city of Dili. Id. 
adequate housing has caused disputes and violence among East Timorese. ${ }^{65}$ Additionally, there has been a fury of land claims since the country gained independence. $^{66}$

\section{The CONSEQUENCES OF EASt TimoR's Tumultuous PAST}

\section{A. A Unique Situation}

East Timor presents a unique situation because it is not only a postconflict environment, but it is also a post-colonial environment. ${ }^{67}$ East Timor is facing problems associated with post-conflict environments, such as the return of refugees, inadequate shelter, restoration of land records, and restoration of institutions of governance. ${ }^{68}$ East Timor is also facing problems associated with a post-colonial environment, including: implementing a new government, building new infrastructure, and employing a method with which to resolve land conflicts. ${ }^{69}$ Thus, East Timor is a country that, although now independent, still has a long and difficult road ahead. It faces not only one bundle of problems associated with decolonization, but a second bundle of severe issues

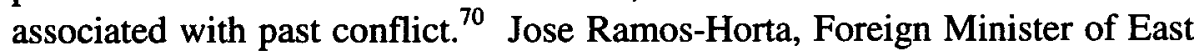
Timor, summed up the situation in East Timor when he described the task of rebuilding the new nation: "we are starting from absolutely ground zero."71

\section{B. The Four Categories of Land Claims}

The events that occurred after the Referendum in East Timor sparked an abundance of land claims. ${ }^{72}$ The land claims brought by people were not based only on land lost during the period after the Referendum, but also from various times throughout East Timor's history. ${ }^{73}$ There exist "four categories of potential claimants for land in East Timor": traditional occupiers of land, those

65. Id. at 10 .

66. See generally id. (explaining the problems with the current state of the land tenure system).

67. See id. at 1.

68. Daniel Fitzpatrick, Land Policy in Post-Conflict Circumstances: Some Lessons from East Timor, J. OF HUMANITARIAN ASSISTANCE (2001), http://www.reliefweb.int/rw/rwb.nsf/AlldocsbyUNID/ca96eed98e8813f2c1256b37003a17f2.

69. Id. East Timor not only has had to deal with a "wave of dispossession," but also problems associated with Portuguese colonization and Indonesian invasion and occupation. Fitzpatrick, supra note 2, at 178.

70. See generally Fitzpatrick, supra note 2.

71. GREENLEES \& GARRAN, supra note 28, at 306 . Horta remarked that not only was the country lacking basic needs, such as "doctors, dentists, accountants, lawyers, and police, but also tables chairs, pots, and pans." Id.

72. See generally FITZPATRICK, supra note 7 (describing the various types of land claims).

73. See generally id. Fitzpatrick describes the situation in East Timor as "most challenging." Id. at 1 . 
who derived land under Portuguese title, those who derived land under Indonesian title, and those in current possession of the land. ${ }^{74}$

\section{Traditional Occupiers of Land in East Timor}

The first category of claimants includes traditional occupiers who have held "customary rights to land." "75 Most land in rural areas of East Timor is "not registered in any formal system of land administration and remains [utilized] in accordance with traditional processes and institutions.",76 Generally, land held by traditional occupiers is held in "community-based" groups in customary tenure systems. ${ }^{77}$

Communal land systems may create and perpetuate East Timor's land and financial problems, which may not make it the best type of land claim for East Timor to recognize. ${ }^{78}$ First, no single individual owns the land and there is often little incentive to invest in the land. ${ }^{79}$ Because community-based groups may not invest in the land, the result is land in the hands of users who are not productively using the land to its fullest economic potential. ${ }^{80}$ Second, because the land is held in community control no one from inside the community can sell the land to anyone outside of the community. ${ }^{81}$ This restriction on alienation creates a situation in which land cannot be used as security for credit, and thus, ultimately decreasing the chances and opportunities for developing

74. Id. at 15. Daniel Fitzpatrick has written extensively on this subject and his work is the basis of this Note's section regarding the four claims to title. In 2000, Mr. Fitzpatrick, Senior Lecturer, Faculty of Law at Australian National University, served as a legal consultant to the United Nations Transitional Administration in East Timor. The Australian National University, ANU College of Law - Our Staff, http://law.anu.edu.au/scripts/staffdetails.asp?StaffID=26 (last visited Mar. 19, 2007) (hereinafter Australian National University). In 2002, Mr. Fitzpatrick published Land Claims in East Timor, a work described by Sir Gerard Brennan, former Chief Justice of the High Court of Australia, as "profound academic scholarship." Id. See generally FITZPATRICK, supra note 7.

75. FITZPATRICK, supra note 7, at 168; see generally PEDRO DE SousA XAVIER, DIRECÇÃo

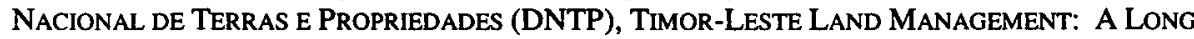
WAY To Go, BUT WE HAVE STARTED (2005), www.fig.net/commission7/bangkok_2005/papers/6_3_sousa_ppt.pdf.

76. FITZPATRICK, supra note 7, at 167. See generally HERNANDO DE SOTO, THE MYSTERY of CAPITAL: Why Capitalism TRIUMPHS IN THE West aNd FaILS EVER YWHERE Else (1941) (discussing capitalism and its relation to the legal structure of property).

77. Id. at 168.

78. Id. at 169. The arguments presented in this section have "had considerable influence on land policy in the developing world. They led, for example, to the outright rejection of customary tenure systems in Kenya, Malawi, Uganda, and Guinea." Id. at 170 . Recently, the World Bank has tried to counteract these arguments by providing arguments supporting customary tenure systems. Id.

79. Craig Richardson, The Collapse of Zimbabwe IN tHe WaKe of the 2000-2003 LAND REFORMS 51 (2004). This is a classical example of the "tragedy of the commons." Id. at 54. See also FITZPATRICK, supra note 7, at 170.

80. FrrZPATRICK, supra note 7, at 170.

81. Id. at 169. 
the land. ${ }^{82}$ Third, "traditional forms of tenure [can] cause unsustainable overconsumption of natural resources on land." $\$ 33$ "Communal farming methods are a recipe for disaster" because group members have no incentive to limit their intake, which results in destruction of the land. ${ }^{84}$ These arguments suggest that land held in customary tenure systems is both harmful to the land and unproductive, which indicates that recognizing land claims from traditional occupiers might not be the best choice for East Timor. ${ }^{85}$

On the other hand, it is important to note that the World Bank has recently changed its views on tenure systems. ${ }^{86}$ It has found that communal land systems can still provide incentives for owners to invest in the land and not deplete land of its natural resources. ${ }^{87}$ Furthermore, the World Bank suggests land that cannot be used to access credit can still be used productively ${ }^{88}$ This competing view on traditional land systems "has led a large number of developing countries to seek to build on traditional tenure systems rather than replace them." ${ }^{89}$

\section{Land Owners during Portuguese Rule}

The second category of claimants includes those who acquired title to land during Portuguese rule over East Timor. ${ }^{90}$ An estimated 2,483 titles were issued in East Timor during Portugal rule. ${ }^{91}$ Claims made by these people include titles to very valuable land. ${ }^{92}$ To recognize these claims would result in "a small colonial elite" holding large amounts of land in East Timor. ${ }^{93}$

Nevertheless, there are "strong moral and legal arguments" as to why the Portuguese land titles should be recognized. ${ }^{94}$ The law of belligerent occupation is an idea developed during the 1899 and 1907 Hague Conventions on Land War. ${ }^{95}$ Basically this principle finds:

82. Id. at 170 .

83. Id.

84. RICHARDSON, supra note 79, at 51. See also FITZPATRICK, supra note 7, at 170.

85. See e.g., FITZPATRICK, supra note 7, at 167-70. See generally RICHARDSON, supra note 79, at 58-63 (comparing communal lands and land individually owned in Zimbabwe).

86. FITZPATRICK, supra note 7 , at 170.

87. See id. at 170-71. The World Bank notes several studies that have found that due to the "strength of social ties and community obligations" individuals are prevented from over consuming and "taking more than their share." Id. at 172.

88. Id. at 171. The World Bank cites "certain successful agricultural industries in Africa [that] have been created without access to formal credit or registered titles." See id. at 170.

89. Id. at 172.

90. See id. at 141. These are people who acquired title pre-1975. Id. The "Portuguese issued land titles, known as 'Alvara." XAVIER, supra note 75.

91. FITZPATRICK, supra note 7 , at 44.

92. Id. at 141. Land claimed includes important urban property and plantation land. Id.

93. Id.

94. Id.

95. Convention Respecting the Laws and Customs of War on Law, with annexed Regulations, 36 Stat. 2277, TS No. 539, 205 Parry's TS 277, Oct. 18, 1907 [hereinafter 
occupation leads to administrative control but not sovereignty. The general rule is that the occupier is required to respect "unless absolutely prevented" the laws in force in the territory at the time of the invasion. This has been interpreted to mean that the occupier may not extend its own law and legal system to the occupied territory, and may not establish a new court system. [Furthermore,] the occupier must respect private property and refrain from pillage or confiscation. ${ }^{96}$

An important aspect of belligerent occupation is that the land is occupied and not annexed. ${ }^{97}$ Little doubt exists that Indonesia occupied East Timor and thus, was a belligerent occupier. ${ }^{98}$ Ultimately, this means "Portuguese law remained the underlying law of East Timor during the period of Indonesia's occupation."99 Taking this viewpoint means that land titles issued under Portuguese rule should have been recognized during the period Indonesia occupied East Timor. ${ }^{100}$ It further leads to the presumption that land titles acquired in East Timor during Portuguese rule should still be recognized today. ${ }^{101}$

Customs of War]. See also FITZPATRICK, supra note 4, at 46. Fitzpatrick finds that "a number of scholars also claim that both the Hague Conventions and the Fourth Geneva Convention have entered international customary law. If this is so, under general principles of international law, Indonesia is bound by the Hague Regulations notwithstanding that it is not a party to the Hague Conventions." Id.

96. FITZPATRICK, supra note 7, at 46-47. See generally D.A. GRABER, THE DEVELOPMENT OF THE LAW OF BELLIGERENT OCCUPATION 1863-1914 (1949). There are exceptions to principles stated in the text of this Note:

First, an occupier may change the law where it is 'absolutely prevented' from doing otherwise. Second, an occupier may take all steps necessary to maintain public order and civil life. Third, an occupier may requisition such property as is necessary for military purposes. Fourth, an occupier may take possession of all movable property belonging to the enemy state that 'may be used for military operations' ....

FITZPATRICK, supra note 7, at 47 (alteration in original) (citations omitted). These are the “"military necessity principles." Id.

97. See FITZPATRICK, supra note 7, at 47 . To determine if an occupier is occupying a country or has annexed a country, one must determine if the "annexation involved armed conflict between two sovereign powers" and if the "annexation was unlawful under the rules of the international law." Id. at 49. If both of these factors are answered affirmatively, then the law of belligerent occupation applies. $I d$.

98. Id. at 51. East Timorese never welcomed Indonesian troops throughout the twentyfour year occupation. See id. at 52-54. Furthermore, there is nothing to indicate that East Timor wanted Indonesia to colonize it. Id. at 52 . This idea is bolstered by the fact that Indonesia entered East Timor with force. See id. at 52-53.

99. Id. at 141. It is important to note that Portugal's status in East Timor was that of a sovereign power, whereas "Indonesia never appears to have gained sovereignty over East Timor." Id. at 143.

100. See id. at 166.

101. See id. at 145. Fitzpatrick adds, "there is nothing to prevent [the government] from non-discriminatory adjustment of these titles without payment of compensation to their East Timorese holders." Id. 
Nevertheless, there are many problems associated with recognizing titles acquired during Portuguese rule. First, it would dispossess a large amount of people who purchased their land under Indonesian rule and who view themselves as bona fide landholders. ${ }^{102}$ Second, it would dispossess many traditional occupiers who "re-took possession of Portuguese titled land after 1975, or after the Indonesian withdrawal in September 1999."103 Third, it would likely cause political conflicts between the liberals and conservatives because it would enable many conservatives to repossess land they owned prior to $1975 .^{104}$ Finally, it would result in placing a large amount of valuable land in the hands of Portuguese, which would result in a "colonial system of land ownership." 105 Despite arguments against recognizing title acquired under Portuguese rule, however, the idea of belligerent occupation remains, suggesting that Portuguese titles should be recognized. ${ }^{106}$

\section{Land Owners During Indonesian Rule}

The third category of claimants includes those who acquired title to land during Indonesian rule over East Timor. ${ }^{107}$ An estimated 34,965 titles were issued by Indonesia in East Timor between the years of 1975 and $1996{ }^{108}$ East Timorese acquired some of these titles, but wealthy Indonesian families and Indonesian corporations acquired a larger amount. ${ }^{109}$ In addition to the private property titles, Indonesia also "took over former Portuguese state property." 110 On this land, Indonesia built new government buildings and housing for Indonesian civil servants." Indonesia is now claiming "recognition of, or compensation for, all of these types of Indonesian titles."112

If the law of belligerent occupation is applicable, then it "may cast doubt on the validity of Indonesia's claim for recognition of private Indonesian titles, and compensation for state or public property." 113 Applying the law of belligerent occupation would harm those East Timorese who acquired land

102. See id. at 141-66. This group includes East Timorese who obtained title to land during Indonesian occupation or have "been in long-term occupation of Portuguese title land since 1975." Id. at 142.

103. Id. at 42.

104. Id.

105. Id.

106. See generally id. at 46-49 (discussing the idea of belligerent occupation).

107. See generally id. at 44-140 (chapters discussing those people that acquired title to land from Indonesia).

108. Id. at 44.

109. Id.

110. Id.

111. Id.

112. Id. at 45.

113. Id. Fitzpatrick notes there may be another way to solve East Timor's land claims problem other than by use of the law of belligerent occupation. See id. He states that "[in] many post-communist countries . . . compensation or property restitution laws have been enacted for the benefit of pre communist owners of private property." Id. 
under Indonesian rule. ${ }^{114}$ Furthermore, to find the titles acquired under Indonesian rule invalid would "[appear] to conflict with certain emerging international norms relating to housing security and protection against unreasonable evictions." 15 Therefore, a dilemma exists between invalidating titles acquired during Indonesian rule, which would result in the eviction of East Timorese, and recognizing these titles, which would overwhelmingly give land rights in East Timor to Indonesians. ${ }^{116}$

\section{Current Possessors of Land}

The fourth category of claimants includes those that are currently occupying land. ${ }^{117}$ Due to the massive population displacements in 1975, when Indonesia entered East Timor, and after the Referendum in 1999, "the extent of informal land occupation by migrant or displaced groups in East Timor is particularly high." 118 By April 2000, most homes in Dili, the capital city of East Timor, ${ }^{119}$ were occupied by people other than their former owners and were severely overcrowded. ${ }^{120}$ In addition to claims by original owners of land, individuals that entered into land contracts with people that were not the rightful owners of the land are also bringing claims as bona fide purchasers. ${ }^{121}$

A variety of concerns arise with this group of claimants. ${ }^{122}$ East Timor could protect these people by passing legislation. ${ }^{123}$ There are three ways to accomplish this. ${ }^{124}$ First, "legislation could provide for protection against eviction of any occupiers who lack alternative land for housing and cultivation." 125 Second, legislation could allow a formal right to land if a person has occupied the land for at least twelve years. ${ }^{126}$ Finally, legislation could allow those currently occupying land the opportunity to gain formal legal rights to the land if they obtained it in good faith and were not on "notice of prior claims." ${ }^{27}$ These forms of legislation would prevent massive evictions

114. See id. at 63.

115. Id.

116. See id.

117. Id. at 205.

118. Id.

119. See WHEELER, supra note 1 , at 54 .

120. FITZPATRICK, supra note 7, at 10.

121. See id.

122. See id. at 204-05.

123. Id. at 205.

124. Id.

125. Id.

126. Id. This is an adverse possession idea; adverse possession is "a method of acquiring title to real property by possession for a statutory period under certain conditions, esp. a nonpermissive use of the land with a claim of right when that use is continuous, exclusive, hostile, open, and notorious." BLACK's LAW DictionaRY 22 (Bryan A. Garner ed., 2nd pocket ed. 2001).

127. FITZPATRICK, supra note 7, at 205. Allowing this type of legislation would be extreme because it would hurt land title holders, be it from the Indonesian era or when Portugal ruled, 
but would also "diminish the prospects of claims by Portuguese or Indonesianera titleholders and potentially reward opportunistic occupations.",128

\section{The Impact of the Land Crisis on People}

East Timor's complicated land tenure problems have greatly affected East Timorese and individuals that own land in the country. ${ }^{129}$ For example, land tenure uncertainty has posed an obstacle for an Australian businessman who purchased hotel property in Dili in 1971 under Portuguese title. ${ }^{130}$ In 1974, the land owner and his family fled East Timor because the Indonesian military threatened to kill any foreigners in Dili. ${ }^{131}$ After the land owner and his family left, the Indonesians took control of the hotel and ran it until 1998. ${ }^{132}$ The land owner then returned to East Timor and was able to convince the Indonesian authorities that he was the owner of the hotel; ${ }^{133}$ however, the Referendum occurred and violence quickly ensued. ${ }^{134}$ The land owner and his family again fled East Timor. ${ }^{135}$ The land owner has again returned, but the new East Timor government has refused to acknowledge his ownership of the property. ${ }^{136}$

Similarly, another family leased property from the Portuguese government prior to 1975 and has had trouble establishing property rights with the new East Timor government. ${ }^{137}$ The family remained on the property after Indonesia occupied the country but did not pay rent. ${ }^{138}$ Now that East Timor is independent, the government is claiming the land back and is trying to evict the family. ${ }^{139}$

Many Portuguese families who owned land in which coffee was harvested fled East Timor when Indonesia invaded the country. ${ }^{140}$ These families left their properties with caretakers. ${ }^{141}$ After a while, many caretakers sold the land without the permission of the owners. ${ }^{142}$ Now these Portuguese families are returning to find their land gone and are making attempts to reclaim

and reward squatters. See id.

128. Id.

129. See FITZPATRICK, supra note 7, at 1 .

130. Rod McGuirk, Asia: Favaro Land Case Takes New Twist, AUSTL. GEN. News, Sept. 3, 2001.

131. Id.

132. Id.

133. Id.

134. Id.

135. Id.

136. Id.

137. Damien Carrick, Property Rights: East Timor; Adverse Possession (radio broadcast Apr. 13, 2004), available at http://www.abc.net.au/m/talks/8.30/lawrpt/stories/s1083899.htm.

138. Id.

139. Id.

140. Commonwealth of Austl., Land Titling in East Timor (2002), http://www.ausaid.gov.au/closeup/etimor/titling.cfm.

141. Id.

142. Id. 
their property. ${ }^{143}$

These cases represent just a few of the thousands of land claims that have arisen. ${ }^{144}$ East Timor's tumultuous past has created a land tenure problem that is complex and may take many years to resolve. ${ }^{145}$

\section{Reasons Why Land Tenure Problems in East Timor Need to be Solved}

Land tenure problems are vitally connected to many aspects of a country's well-being, specifically its economic and political stability. ${ }^{146}$ In order for the young nation of East Timor to prosper, the country must ascertain ways to cure the current state of its land tenure system. ${ }^{147}$

East Timor has always struggled financially. As a Portuguese colony, the country was highly impoverished; as a colony of Indonesia, it was Indonesia's second poorest colony. ${ }^{148}$ There is a general consensus among economists that property "is vital to sustainable economic development." people are less likely to want to invest and build infrastructure or plant crops in regions that lack formal property rights. ${ }^{150}$ There is a "dramatic effect on work incentives when individuals feel secure that the product of their work efforts will not be stolen from them."151 Furthermore, foreign companies do not want to invest in a country unless they can be guaranteed private land ownership rights. ${ }^{152}$

East Timor has natural resources that could be of great economic benefit to the country, but that can only be fully utilized through the establishment of an enforceable land tenure system. ${ }^{153}$ Thus, the country's economic vitality rests upon the resolution of its land claim problems. ${ }^{154}$

The success of a country depends highly on its political stability. ${ }^{155}$ East

143. Id.

144. See Carrick, supra note 137. See also RICHARDSON, supra note 79, at 11 (finding that "countries that first recognized the importance of property rights were the ones that saw the fastest economic growth."). Timor).

145. See generally FITZPATRICK, supra note 7 (describing the land claims problems in East

146. See DEKKER, supra note 7, at 82-83.

147. See generally FITZPATRICK, supra note 7 (suggesting solutions for East Timor's land claims problems).

148. KINGSBURY, supra note 37 , at 409.

149. Fitzpatrick, supra note 2, at 177.

150. Id.

151. RICHARDSON, supra note 79 , at 15.

152. Fitzpatrick, supra note 2, at 177.

153. Id. East Timor has oil fields, "a strong coffee production industry," and a beautiful, natural landscape that could provide the country with profitable tourism opportunities. KINGSBURY, supra note 37 , at 410.

154. See generally Fitzpatrick, supra note 1 (discussing the dire state of the country's economy).

155. See generally id. at 193-206 (discussing the need for a "'political order support of broad economic goals' such as prosperity, social justice and national unity"). Id. at 193. 
Timor's current land problems have created political instability in that "[n]oone wants to create a legal solution to the problem because everyone worries that that legal solution will deny them their own rights." 156 Thus, politics have played a huge role in East Timor's lack of beneficial land reform, as the country's political officials have resorted to ad hoc solutions that benefit the politically powerful. ${ }^{157}$ This political corruption exemplifies the way in which land tenure issues can be interconnected with problems in the internal structure of a country and further indicates the need to cure land tenure problems.

\section{LAND TENURE REFORM}

Land reform is a "deliberate act to change the existing land tenure."158 It is commonly thought to only apply to agricultural land,${ }^{159}$ however, land reform applies to "changing the tenure situation of all real property." ${ }^{160}$ Land reform is generally motivated by the need to "modernize agriculture or to redress inequalities in the distribution of land assets," or for a combination of these two reasons. ${ }^{161}$ Land is redistributed, which often results in the government taking land from those who possess large amounts and giving it to poor, landless individuals. ${ }^{162}$ This method of redistribution can significantly help a country's economy because it gives peasants the ability to make a living off the land. ${ }^{163}$ It is important to note, however, that land reform can also result in subsistence farming. ${ }^{164}$

It is imperative that land reform programs are developed specifically for the country in need; there is no standard formula or method by which to reform land. ${ }^{165}$ In general, land reform programs should have a system that allows

156. Carrick, supra note 137.

157. Id.

158. DEKKER, supra note 7, at 77. Land reform is non-evolutionary. Id. Also, there is a difference between land reform and agrarian reform. Id. Agrarian reform is a "complex of changes in rural structure that occur as a matter of passing of time, as a governmental supported activity to assist farmers in achieving more efficient agricultural land use, but also always as part of land redistribution processes either on purpose or as a side-effect." Id. at 78. Agrarian reform is mostly used to fight rural poverty. Id.

159. Id. "Land reform is the deliberate act to change the existing land tenure in a rural area making it a non-evolutionary way to change land tenure." Id. at 77 .

160. Peter Jacobs et al., Land Redistribution, Programme for LAND AND Agrarian STUDIES, Sept. 2003, at 1.

161. DEKKER, supra note 7, at 77. Evidence from some former communist countries indicates that large farms are not nearly as agriculturally productive as small farms. Id. at 79 .

162. Id. at 78. Land reform usually occurs for political reasons and if carried out throughout the country generally needs the support of foreign donors for its funding. Id.

163. Jacobs et al., supra note 160 , at 1.

164. Maura Andrew et al., Land Use and Livelihoods, PROGRAMmE FOR LAND AND AGRARIAN STUDIES, Aug. 2003, at 1. Using land in this way is "generally viewed as wasteful, destructive and economically unproductive in comparison to commercial production systems." Id.

165. DEKKER, supra note 7 , at 80 . For this reason land reform programs are not completely comparable, nor can a successful land reform program in one country be expected to yield the 
loans that use "land as collateral, and provide education to new farmers." 166 In addition, governments need to provide "physical infrastructure," such as roads and utilities. ${ }^{167}$ It is also important for a country to use a "continuum of farmers' approach." "168 This approach recognizes "and supports a broad range of large and small-scale, full-time and part-time, as well as commercial, peasant and subsistence farmers." 169

Land reform can provide stability and enable a country to prosper. ${ }^{170}$ First, it provides these benefits by decreasing political conflict, thereby providing a country with political stability. ${ }^{171}$ Without political stability land is often "misallocated," resulting in thousands of peasants without land and a viable source with which to support themselves. ${ }^{172}$ Frequently, peasants' dissatisfaction with this situation results in the formation of groups that rebel against the country's government and its failure to provide them with land. ${ }^{173}$ In an effort to maintain peace and political stability, many countries turn to land reform. ${ }^{174}$ Another political reason to reform land is to "show the world" that a country is working toward economic and social development. ${ }^{175}$ Second, land reform may provide a country with economic growth. "176 "Improved access to land [allows] the rural poor to make more productive use of family labor," which may stimulate a country's economy. ${ }^{177}$ Studies indicate the more security there is in land tenure, the more farmers harvest. ${ }^{178}$

Two things must occur to successfully reduce poverty through the use of land reform. ${ }^{179}$ First, "the poor must have access to the land; [second], the poor must be assisted with sufficient resources and an enabling institutional framework for them to base their livelihood on the land."180 A land reform

same results in another country. Id. at 105.

166. Id. at 81; See, e.g., LAND REFORM IN ZIMBABWE: CONSTRAINTS AND PROSPECTS 129 (T.A.S. Bowyer-Bower \& Colin Stoneman eds., 2000) [hereinafter LAND REFORM IN ZIMBABWE].

167. DEKKER, supra note 7, at 81 . Roads are needed to allow new land owners "access to their fields and to transport cattle, harvests and crops." Id.

168. Andrew et al., supra note 164 , at 1 .

169. Id. The alternative approach is dualistic in nature and assumes farming is either commercial or subsistent in nature. Id.

170. DEKKER, supra note 7, at 82-83. Liberation theology is another motive suggested by Dekker, but it will not be discussed in this Note. For further discussion of this theory, see generally $i d$. at 83-84.

171. See Ben Chigara, Land Reform Policy: The Challenge of Human Rights Law 8 (2004). See also DEKKER, supra note 7, at 82.

172. See DEKKER, supra note 7 , at 82.

173. Id. "Land reform in the 1960 s was largely motivated by the fear of insurgencies and political unrest." Id.

174. See id. at 103.

175. See id.

176. Id. at 83.

177. Id.

178. Id.

179. TUlani Sithole \& GoOdHope Ruswa, ZimbabWE's LAND ReForm ProgrammE: AN AUdTT OF THE PUBLIC PERCEPTION 2 (2003).

180. Id. 
lacking either of these two components is likely to be unsuccessful in reducing poverty. ${ }^{181}$

Land reform cannot be expected to completely absolve a country of its problems. ${ }^{182}$ Furthermore, land reform programs often come with criticism. ${ }^{183}$ Thinking of land reform in strictly the agriculture sense, it is argued that " $[t]$ he youth of most of the rural regions feel that anything is better than working on a small farm with all of its uncertainties like disappointing harvests, pests, credit debts, droughts [sic] etc." 184 These people find that the increasing importance of technology is decreasing the importance of land. ${ }^{185}$ Also, many argue that private property is a "near-sacred [right]" that should not be taken away to redistribute to landless individuals. ${ }^{186}$ Thus, it is important for a country to carefully ascertain the benefits that might be gained by land reform, but also keep in mind the detrimental effects associated with it. ${ }^{187}$

\section{LAND REFORM IN SOUTH AFRICA}

\section{A. History of Dispossession}

South Africa's history "is marked by a series of incidents in which European settlers dispossessed indigenous South Africans of their land.", 188 The course of dispossession occurred gradually; it first started in the mid-1600s when Dutch settlers invaded the Cape, and continued up until the twentieth century when Europeans began "[segregating] land ownership by race.", Initially, Africans "welcomed the settlers," but little did they realize that these settlers would soon oust them from their native lands. ${ }^{190}$ By 1910 , the British population had exponentially increased due to "the discovery of diamonds and gold in the late 1800s."191 A government composed of white Europeans passed policies that restricted, and in some cases denied, Africans of their property rights. ${ }^{192}$ Ultimately, these policies drove the Africans out of their land. ${ }^{193}$

In 1913, the Natives Land Act was enacted and proved to play a major

181. Id.

182. DEKKER, supra note 7, at 102.

183. See id. at 107.

184. Id.

185. Id.

186. Id. This is a natural law idea. Id.

187. See generally id. at 103-07 (evaluating land reform).

188. Lauren G. Robinson, Rationales for Rural Land Redistribution in South Africa, 23

BROOK. J. INT'L L. 465, 468 (1997).

189. Id.

190. Id. at 470-71. Several wars were fought between European settlers and Africans. Id.

191. Id. at 471 .

192. Id. at 472 .

193. Id. 
role in moving the region towards apartheid and segregation of the races. ${ }^{194}$ This Act "set aside seven percent of the surface area of South Africa as reserves or scheduled areas as territories where only Blacks, who comprised more than seventy-five percent of the population, could purchase property."195 The 1913 Act created a devastating situation for Africans, which was only slightly improved by the 1936 Native Land and Trust Act. ${ }^{196}$ The 1936 Act "increased the land available for Black ownership to $13.6 \%$ of the country's surface area." 197 However, this increase in the amount of available land to Africans was accompanied by a provision denying Africans on the land reserves the right to obtain "direct ownership" of land. ${ }^{198}$

By 1948, South Africa was under apartheid and laws were "entrenched [with] White privilege."199 Racial segregation was not only socially accepted, but it was legally mandated. ${ }^{200}$ Apartheid was justified on the "basis of an ideology of White supremacy and the alleged racial inferiority of Africans."201

During the period between 1960 and 1983, white farmers and the government forcibly removed Africans from non-Native areas. ${ }^{202}$ The reserves were transformed into the homelands and "Africans were banished" to this area, which was not large enough to sustain such a large population. ${ }^{203}$ Essentially, Africans were treated as "foreigners in their own country." 204 It is estimated that during this time approximately 3.5 million Africans were removed from their home and deported to areas called the homelands. ${ }^{205}$

194. Id.

195. Id. In addition, land transactions consisting of land outside of the reserves could not take place between Blacks and persons that were not Black. Id. at 472-73. This resulted in diminished opportunities for Africans to earn high incomes because they could not engage in sharecropping arrangements with White farmers. Id. at 473.

196. See id. at 475.

197. Id.

198. Id. "The [1936 Act] substituted individual land ownership with trust tenure by establishing the South African Development Trust, a government body which purchased land in the released areas for 'Black settlement."' Id. Additionally, Parliament passed laws that "created racially segregated sections in the urban areas" and restricted African's abilities to obtain land in urban areas. I. . These laws were called the Urban Areas Consolidation Act of 1945. Id.

199. Id at 476. See also CHIGARA, supra note 171 , at $18-20$.

200. Robinson, supra note 188 , at 476 . This situation occurred shortly after the National Party gained control of South Africa's government. Id. The National Party was able to maintain support by subsidizing "White farmers in exchange for their political loyalty." Id.

201. Id. During this time, a complicated system of racial classifications was developed. $I d$. Whites composed one racial group, while Blacks were broken into various different categories based on tribal affiliations. Id. 476-77.

202. Id.

203. Id.

204. Id. at 478.

205. Id. at 479. The land given to the Africans in the homelands in exchange for their homes was not an equivalent trade. Id. In the homelands there was a land shortage, which made it hard for Africans to obtain farm land. Id. at 480 . This created high poverty rates in the homelands. Id. at 481 . 
In 1990, almost fifty years later, the apartheid government began to repeal statutes governing segregation. $^{206}$ By 1991, the Land Acts from 1913 and 1936 were repealed. ${ }^{207}$ Shortly thereafter, a "multi-racial transitional government" formed to rid South Africa of apartheid. ${ }^{208}$ In 1994, Nelson Mandela was elected president and by 1996 the country had adopted a new constitution. ${ }^{209}$

\section{B. The Redistribution of Land}

"The post-apartheid government ... inherited the land problem, as well as" the dissatisfaction of Africans in South Africa. ${ }^{210}$ The exclusion of apartheid laws in the late 1980s created "a massive movement of people from [neighboring] countries into South Africa"; this only added to the already immense land problems for the country. ${ }^{211}$ However, South Africa acted fast to create solutions to the land problems facing the country. ${ }^{212}$ In an effort to prevent an "economic meltdown," the government continued to encourage foreign investment while at the same time continuing efforts to provide land to the "landless" people of the country. ${ }^{213}$ A land reform program was developed in 1994 with the goal to redistribute thirty percent of "agricultural land between 1994 and 1999 through restitution, redistribution, and tenure reform [programs]."214

The land tenure program did not prove to be as successful as the government had hoped; a mere forty-one out of 63,000 claims were settled. ${ }^{215}$ Over half of South Africans are still "landless and need land."216 Additionally, "[a]chieving greater equality in land ownership and improving the livelihoods of rural people" proved to be a huge challenge."217

There are many reasons advanced for the land reform program's failure. $^{218}$ One criticism is that the government has remained committed "to a neoliberal macroeconomic [program]," which has slowed efforts to redistribute land because the program relies on a "willing buyer, willing seller'

206. Id. at 482 .

207. Id.

208. Id. See also Jacobs et al., supra note 160 , at 1.

209. Robinson, supra note 188 , at 483.

210. Mfaniseni Fana Sihlongonyane, Land Occupations in South Africa, in RECLAIMING THE LAND The RESURGENCE Of RURAL MOVEMENTS IN AFRICA, AsIa AND LATIN AMERICA 142, 142 (Sam Moyo \& Paris Yeros eds., 2005).

211. See id. at 146.

212. See id. at 150.

213. See id.

214. Id.

215. Id. A huge part of this problem is attributed "to the fact that after eight years of postapartheid government, 55,000 farmers still own more than 80 per cent of the land, some of which is not being productively used." Id.

216. Id.

217. Jacobs et al., supra note 160 , at 5.

218. Sihlongonyane, supra note 210 , at $150-52$. Note that women's' ability to purchase land is limited because the market is an area reserved predominantly for men. Id. at 151 . 
principle."219 This approach presents a problem; land prices are often inflated and after a buyer purchases land they are left with few resources with which to improve the land by way of building homes and engaging in farm production. ${ }^{220}$

Another reason offered to explain the failure of land reform efforts is the lack of connectivity between the Department of Land Affairs (DLA) and other departments in the government. ${ }^{221}$ Ultimately, this has resulted in land reform losing importance on the country's "political agenda."222 There are various groups ${ }^{223}$ maintaining efforts to resolve land issues; however, the fight for land reform is "fragmented."224 The lack of cohesion and organization between these groups results in a lack of structure or coherent means by which to pursue goals to reform land in South Africa. ${ }^{225}$

Additionally, the government has by and large failed to consider the needs of its people. ${ }^{226}$ Land reform should be applied gradually and flexibly, while at the same time keeping in mind those that are "intended to benefit" from the land reform programs. ${ }^{227}$ Furthermore, it is argued that the failure to educate individuals in the area about land reform and the ways by which it should occur has aided in the failure of the program. ${ }^{228}$

\section{LAND REFORM IN ZIMBABWE}

\section{A. History of Dispossession}

In 1895, Zimbabwe was called Rhodesia, after Cecil Rhodes, ${ }^{229}$ and was

219. Id. at 150 . This method is dependent on current owners voluntarily selling their land. Jacobs et al., supra note 155 , at 3 .

220. See Sihlongonyane, supra note 210 , at 150 . Furthermore, land is advertised as farm land, yet it has "low agroecological value" because it was destroyed by white farmers during apartheid. Id.

221. Id.

222. Id. "More fashionable and politically rewarding issues, such as HIV/AIDS, poverty and the environment" have taken precedent over land issues for NGOs (non-governmental organizations). Id. at 158.

223. Id. at 153. These groups include the Association of Rural Advancement (AFRA), the Surplus People's Project (SPP), the Transvaal Rural Action Committee (TRAC), and the Border Rural Committee (BRC). Id. These organizations are affiliated with one another through an organization now called the National Land Committee (NLC). Id.

224. Id. at 158.

225. Id.

226. See id. at 159. Instead the government has chosen to focus on the market aspect when dealing with land issues. Id.

227. See Martin Adams et al., Land Tenure Reform and Rural Livelihoods in Southern Africa, NAT. ResOuRCES PERSPECTIVES (1999), available at www.odi.org.uk/nrp/39.html. For example, in some areas land seizure may be the best option, while in other places negotiation may be most appropriate. Sihlongonyane, supra note 210 , at 159.

228. Id. at 160 .

229. Country Review - Zimbabwe, EBSCO, www.iucat.edu.iu.edu (2005) [hereinafter 
considered a "British sphere of influence" because the British South Africa Company (BSAC) administered development of the area. ${ }^{230}$ By 1898 , Britain required the BSAC to create communal areas for the native people of the land. ${ }^{231}$ Thus, "Native Reserves" or "Communal Areas" were developed for the indigenous people. ${ }^{232}$ Despite the limitations on the Native Reserves created for the indigenous people, there was still "adequate land for cultivation, grazing and watering."233 As the BSAC began to realize that agriculture in Rhodesia could be highly profitable, however, it quickly began divesting the natives of lands and placing the land into the hands of white colonists. ${ }^{234}$ By 1923, the number of white colonists had significantly increased, and they were given the choice to join the Union of South Africa or become "a separate entity within the British Empire."235 They rejected incorporation with the Union of South Africa and, ultimately, the United Kingdom took possession of the area. ${ }^{236}$ Rhodesia developed into "an internally self-governing colony with its own legislature, civil service, armed forces and police."237

In 1934, land apportionment acts created land reserved only for Europeans. ${ }^{238}$ These acts enabled Europeans to take over almost one third of all the land in Rhodesia. ${ }^{239}$ Britain pressured Rhodesia to implement majority rule ${ }^{240}$ however, Rhodesia "showed little willingness to accede to African demands for increased political participation." 241 In 1965, Ian Smith became the Prime Minister of Rhodesia and "declared white dominance would be preserved "for a thousand years." Later that year, extensive negotiations took place between Britain and Rhodesia. ${ }^{242}$ These negotiations, however, were fruitless and merely resulted in Prime Minister Smith issuing a "Unilateral

Country Review]. Rhodes priginally moved to Africa as a teenager to live with his brother.

MSN Encarta, Cecil Rhodes, http://encarta.msn.com/encyclopedia_761566082/Rhodes_Cecil_John.html (last visited Mar. 22, 2007). In 1870, "[d]iamond fields were discovered" in the area "and Rhodes became a diamond prospector. By the time he was 19 years old he had accumulated a large fortune." Id. Rhodes later became one of the "main promoters of British rule in southern Africa." Id.

230. Id. Rhodes was able to procure a "concession for mineral rights from local chiefs." Id.

231. Arnold Sibanda, The Millennium Land Policy and the Economics of Farm Occupations by War Veterans in Zimbabwe 3 (Working Paper, June 2000).

232. Id.

233. Id.

234. Id. at 3; see also Country Review, supra note 229 , at 7.

235. Country Review, supra note 229 , at 7.

236. Id.

237. Id.

238. Id. Essentially, Whites had "their pick of the land." BERTUS DE VILLIERS, LAND REFORM: ISSUES AND CHALLENGES 5 (2003).

239. Country Review, supra note 229 , at 8 . It is estimated that "[b]y the end of colonial rule $42 \%$ of the country was owned by 6,000 [white] commercial farmers." DE VILLIERS, supra note 238 , at 6 .

240. Country Review, supra note 229 , at 8.

241. Id.

242. Id. 
Declaration of Independence (UDI) from the United Kingdom."243

The native Africans of the area grew weary about their minority status and lack of political participation and formed groups in an effort to end colonialism. $^{244}$ Two of these important groups were the nationalist Zimbabwe African National Union (ZANU) and Zimbabwe African People's Union (ZAPU). ${ }^{245}$ Prior groups focused on political activity, but these new organizations instead concentrated on military activity. ${ }^{246}$ In late 1965 , the United Nations intervened and declared UDI illegal. ${ }^{247}$ In late 1966, the United Nations for the first time "imposed mandatory economic sanctions on a state" when it prohibited most trade and investment with Rhodesia. ${ }^{248}$

Because of pressure from "embargo-related economic hardships" and "anti-government guerilla activity" by ZAPU and ZANU, Prime Minister Smith agreed to majority rule and to meet with Black Nationalist leaders in Geneva in $1976 .^{249}$ By April 1979, the first black Prime Minister, Bishop Muzorewa, was elected to "Zimbabwe-Rhodesia."

The Lancaster House agreement, signed on December 21, 1979, called for a "ceasefire, new elections, a transition period under British rule and a new constitution implementing majority rule while protecting minority rights." ${ }^{, 250}$ In addition, the "agreement held that the country's name would be Zimbabwe." "251 Robert Mugabe won the elections in 1980 and formed "Zimbabwe's first government." 252 Prime Minister Mugabe stated that "his government would begin investigating ways of reversing past discriminatory policies in land distribution, education, employment, and wages."253

\section{B. Land Reform}

"Since 1890 up to today, the land question has singularly had the most significant impact on Zimbabwe's political and economic history."254 Most recently, the Land Resettlement Program, developed after Zimbabwe's

243. Id. "The British government considered the UDI unconstitutional and illegal but at the same time made clear it would not use force to quell the rebellion." Id.

244. See id.

245. Id.

246. Id.

247. Id. Britain "imposed sanctions on Rhodesia and requested other nations to do the same." Id.

248. Id.

249. Id. at 8-9. The Black leaders in Geneva included the leaders of ZAPU and ZANU and leaders of other organizations. Id. at 9 . The guerilla conflict resulted in the deaths of over 20,000 people in the years between 1972 and 1979. Id.

250. Id.

251. Id.

252. Id.

253. Id.

254. LAND REFORM IN ZIMBABWE, supra note 166 , at 187 . In 1888 , Rhodesia "was proclaimed a British sphere of influence," which was a monumental event in the country's history. Country Review, supra note 229, at 7. 
independence in 1980, has had mixed reviews. ${ }^{255}$ One position is that the program has "resulted in one of Africa's most successful examples of land redistribution." 256 The other position is that the land reform program in Zimbabwe has been disastrous to the country and its economy. ${ }^{257}$ According to some sources, a total of over 3.5 million hectares of land have been resettled. ${ }^{258}$ But, "[t]here is considerable controversy on the number of people who have [actually] been allocated land.",259

Between the years of 1980 and 1990, Zimbabwe adhered to a model based upon a "willing-buyer, willing seller' basis," which was an idea based on the Lancaster House Agreement. ${ }^{260}$ During the 1980 s, the country had a goal to resettle approximately 162,000 families. ${ }^{261}$ Despite the country's success in resettling approximately " 58,000 [families] on 3 million hectares of land, [and] reducing the white commercial farming sector to . . 29 per cent of agricultural land," the country fell short of its goal. ${ }^{262}$ Furthermore, a survey of people resettled onto new land found that those people regarded it as a "'mixed blessing', and [for the] most [part] felt their families were worse off than those" still living in communal areas. ${ }^{263}$

Shortly thereafter, the 1992 Land Act passed; this Act introduced procedural changes, reduced the size of farms, and created a land tax. ${ }^{264}$ The Act was created in response to criticisms brought in the 1980 s that land reform was progressing slowly due to its basis on market-driven land reform. ${ }^{265}$ With this new Act, however, came new criticisms. ${ }^{266}$ These new criticisms focused on the impacts of land reform on the economy, and "argument [ensued] over who was receiving the land." 267 Evidence indicates that many people who received land during this time were "political associates and supporters" of

255. See SITHOLE \& RUSWA, supra note 179.

256. LAND REFORM IN ZIMBABWE, supra note 166 , at 187.

257. See SITHOLE \& RUSWA, supra note 179.

258. DE VILLIERS, supra note 238, at 20.

259. SITHOLE \& RUSWA, supra note 179 , at 10.

260. LAND REFORM IN ZIMBABWE, supra note 166, at 2.

261. Sihlongonyane, supra note 210, at 173. "The 1979 Lancaster House Agreement had provisions that restricted the government from acquiring land for a period of 10 years." SIrHOLE \& RUSWA, supra note 179 , at 1 .

262. Sihlongonyane, supra note 210 , at 173 . Furthermore, it is important to note that the land resettled this time was primarily of "low agro-ecological value." Id. Additionally, some of the land acquired during this time was. "land that had been abandoned by white landowners in liberated zones of the war, and hence was more easily acquirable." Id. at 183.

263. LAND REFORM IN ZIMBABWE, supra note 166, at 119.

264. Id. at 2 . One procedural change was for land acquisition to be compulsory. Id. In addition, there was "less certainty over what compensation would be paid for land acquired." Id. However, there was still legislation that enabled landowners legal recourse and the "willingbuyer, willing seller method" was not renounced. Sihlongonyane, supra note 210, at 176.

265. Sihlongonyane, supra note 210 , at 176.

266. LAND REFORM IN ZIMBABWE, supra note 166, at 2.

267. Id. 
Zimbabwe's prime minister, Robert Mugabe. ${ }^{268}$ This claim was confirmed when the Utete Commission ${ }^{269}$ was appointed and there was a call for "ruling party 'chiefs', who were largely the multiple farm owners, to surrender additional farms." 270 This order showed that it was not "ordinary poor people" who were reaping the benefits of the land reform program. Instead it was the region's elite and those with political connections who were the primary beneficiaries of the recent land reforms. ${ }^{271}$

By 1997, the economy of Zimbabwe was in sharp decline. ${ }^{272} \mathrm{~A}$ conference with donors to Zimbabwe's land reform program was held in 1998 to determine methods by which to "provide land to the landless.",273 At the conference, it was decided that Zimbabwe would "proceed with both compulsory and market acquisition" methods of obtaining land. ${ }^{274}$ The government failed to follow through with these objectives and little occurred between 1998 and 2000 to accelerate land reform. ${ }^{275}$ Despite this stagnant period, land reform quickly was back on track a short time later; by 2002 the government claimed it had "compulsorily acquired some 10 million hectares of land - approximately $90 \%$ of white commercial farmland - and redistributed most of it to 127,000 peasant households and 8,000 middle capitalist farmers., 276

Despite numbers and statistics given by the Zimbabwe government that tend to indicate the land reform program was successful, the opinions of ordinary Zimbabweans generally indicate a very different view. ${ }^{277}$ A survey ${ }^{278}$ in 2003 identified many shortcomings and problems associated with the land reform program in Zimbabwe. First, "the majority of beneficiaries" of the land reform program were people between the ages of forty and fifty. ${ }^{279}$ Individuals

268. Id.

269. See generally STTHOLE \& RUSWA, supra note 179.

270. Id. at 10.

271. Id.

272. Sihlongonyane, supra note 210 , at 187.

273. LAND REFORM IN ZIMBABWE, supra note 166 , at 47.

274. Sihlongonyane, supra note 210 , at 187.

275. Id. The government continued to ask the people without land to wait. Id.

276. Id. at 188 . The country's land reform policies in the late 1990 s and early 2000 s have been highly criticized because these policies involve a "framework that enables the taking of land without due process." DE VILLERS, supra note 238, at 20-21. In addition, thousands of farms are occupied by rebel groups and the country has failed to address this problem. Id. "[T] he government has revised the constitution and amended legislation in order to allow it to acquire commercial farms compulsorily and without compensation." Human Rights Watch, Fast Track Land Reform in Zimbabwe (2002), available at http://www.hrw.org/reports/2002/zimbabwe/.

277. See generally, SITHOLE \& RUSWA, supra note 179.

278. Id. at 2 . The survey was distributed randomly to 1445 people. Id. It was "divided between males and females and between urban and rural residential areas in proportion to their percentages in the national population." Id. The major limitation of the survey was that people were reluctant to answer some of the questions because of fear of government retaliation. Id.

279. Id. at 11. 
between the ages of eighteen and twenty-four, the future generation of the country, received the least amount of land. ${ }^{280}$ Second, survey participants indicated that land may have been allocated, but that it was not actually occupied. $^{281}$ There are several reasons why individuals failed to occupy allocated land: lack of resources, poor infrastructure, drought, government corruption, and court disputes. ${ }^{282}$ Third, "one of the strongest criticisms of the land reform process in Zimbabwe was its negative effect on production."283 Lastly, many people believed and still continue to believe that the decline in the country's economy is a direct result of the failed land reform program. ${ }^{284}$

Likewise, a report produced in 2000 described the situation in Zimbabwe as a country in complete despair. Specifically, it reported that the land reform program was without regard for "law, order and authority." the "key industrial index of the Zimbabwe Stock Exchange (ZSE) sunk to a 4 month low" during March of $2000 .^{286}$ Furthermore, there were a number of farm occupations occurring and most foreign aid from donor countries had been suspended. $^{287}$ With regard to farm occupations, in 2001 , a white farmer reported to CNN that " 150 black demonstrators overran his farm . . . they [seized] the land and warned him not to plant any new crops. . . [t]he occupiers [planted] almost 90 percent of his fields ... and [t]he future of his farm and the more than 300 people he [employed hung] in the balance."288 This is just one example of over two thousand farm occupations that have occurred. ${ }^{289}$

There are still many discrepancies in the degree of success of Zimbabwe's land reform program. If the data and statistics released by the government are accurate, then the Land Resettlement Program in Zimbabwe is "one of Africa's most successful examples of land redistribution.",290 Yet, surveys and accounts by people living in Zimbabwe suggest something quite

280. Id.

281. Id. at 13 .

282. Id. Allocated land often was not occupied because of legal complexities, which resulted in court litigation. Id. This left "farmers reluctant to occupy and invest on the farms." Id.

283. Id. at 15 . There are many reasons for loss of production: "non availability of fuel," farmers' inability to receive credit, and "lack of farming skills among the resettled farmers." Id.

284. Id. at 26. The Utete Commission, however, contends that the "economic problems in Zimbabwe are not linked to the fast track land reform exercise." Id.

285. Sibanda, supra note 231, at 11. But see Bob Coen, Zimbabwe's Land Reform Still $\begin{array}{llll}\text { Controversial, } & \text { CNN, } & \text { Feb. 2001, }\end{array}$ http://archives.cnn.com/2001/WORLD/africa/02/09/inside.africa, reporting that "[t]he government says the program is organized and sustainable."

286. Sibanda, supra note 231, at 11.

287. Id.

288. Coen, supra note 285 (noting the "government [denied] any involvement in the lawlessness on farms like" the one described in the text). Id.

289. Id.

290. LAND REFORM IN ZIMBABWE, supra note 166, at 187 (finding "[n]o other African country has acquired [3.3 million hectares] of land from private landowners and re-distributed it to the poor and landless."). Id. 
different, painting a picture of mass devastation directly linked to the implementation of land reform. ${ }^{291}$

Nevertheless, many Zimbabweans believe that land reform and redistribution was necessary and remains necessary for the future of the country. ${ }^{292}$ But, land reform programs and redistribution of land in the future will have to use new methods. ${ }^{293}$ Many Zimbabweans found that the Land Resettlement Program was carried out in a way that tended to "punish whites" and enrich those politically aligned with Prime Minister Mugabe. ${ }^{294}$ Additionally, land occupations were found to be a negative aspect of land reform in Zimbabwe. Land occupations began after the 1998 conference and resulted in "over a hundred politically related deaths between 2000 and 2002."295

Zimbabwe continues to suffer with "inequities in land distribution, poverty, and unemployment problems."296 Even if the land reform program is not the sole cause of Zimbabwe's economic problems, it has certainly "exacerbated" the problem and consequently "decreased agricultural production and tourism revenues" for the country. ${ }^{297}$

\section{MEASURES ALREADY TAKEN TO RESOLVE LAND ISSUES IN EAST TIMOR}

East Timor has already started the process of resolving land issues. ${ }^{298}$ The country adopted its constitution on March 22, 2002. ${ }^{299}$ In its Constitution, East Timor provided a safeguard to ensure land for East Timorese by "reserv[ing] land ownership for East Timor citizens only.",300

291. See generally SITHOLE AND RuSWA, supra note 179.

292. Id. at 16 .

293. Id.; see also Robin Palmer, Mugabe's Land Grab in Regional Perspective, Conference on Land Reform in Zimbabwe - The way Forward, at 1, for the following list of problems associated with the land reform program in Zimbabwe: "[1]ack of funds, lack of planning, lack of capacity, [and] lack of accountability."

294. SITHOLE AND RUSWA, supra note 179, at 16

295. Id. at 187-88. Land occupations grew much stronger in 2000. Id. at 190. The occupations "focused on white farms, but also sporadically on farms owned by black capitalists and the political elite." Id. See also Fast Track Land Reform in Zimbabwe, supra note 276, stating "[t]he police have done little to halt such violence, and in some cases are directly implicated in the abuses." Id.

296. The World Bank, Zimbabwe - Country Brief, http://web.worldbank.org/WBSITE/EXTERNAL/COUNTRIES/AFRICAEXT/ZIMBABWEEX TN/0,,menuPK:375746 pagePK:141132 piPK:141 107 theSitePK:375736,00.html (last visited Mar. 22, 2007) [hereinafter World Bank Website].

297. Id.

298. See, e.g., XAVIER, supra note 75 .

299. Const. of THE Democratic Republic of E. Timor (2002).

300. USAID/East Timor, New Computer Database Helps Sort Land Claims Appraisal, (Dec. 14, 2004), http://timor-leste.usaid.gov/PrintVersion/EGArchive17Print.htm [hereinafter New Computer Database]; see also CONST. OF THE DEMOCRATIC REPUBLIC OF E. TimOR $§ 54$. 
In March 2003, the government implemented Law 1/2003 that designated the Ministry of Justice's Directorate of Land and Property (DNTP) as the department having authority over land and property matters in East Timor. ${ }^{301}$ Additionally, this law mandated a timeframe in which land claims were to be made. $^{302}$ March 2004 served as the deadline for land claims. ${ }^{303}$ In December 2004 , a database was developed to help resolve the over 10,000 claims for land that were filed. $^{304}$ The database enables DNTP to analyze the various claims and determine "overlapping or conflicting" claims. ${ }^{305}$ DNTP has been able to solve approximately fifty claims for land. ${ }^{306}$

In February 2004, a report by the Timor-Leste Land Law Program, entitled "A Legal Framework on Land Dispute Mediation," was released to the government. ${ }^{307}$ This report provided the government with "extensive data, detailed analysis, and a mediation mechanism for land disputes based on field research in all 13 of East Timor's districts, more than a third of its sub-districts, and 10 percent of its villages." ${ }^{308}$ Additionally, an organization called Land Law Program of Associates in Rural Development, Inc. (ARD), was formed to assist East Timor in establishing a "land-tenure research center."309

In December 2004 and September 2005, the East Timorese government passed laws regarding the leasing of land. ${ }^{310}$ Specifically, these laws set "the minimum conditions of lease agreements of private property between individuals." 311 These laws were necessary due to the lack of certainty in protection of private property and the government's inability to resolve the thousands of land claims. ${ }^{312}$ Thus, the country is engaging in the leasing of

301. XAVIER, supra note 75. The DNTP's duties include: "legislation and policy proposals, land dispute resolutions, administration of state land assets (immovable property), administration of abandoned property, cadastral survey and mapping, land registry (titles office), valuation and future taxation, [and] national mapping." Id. In Portugal the DNTP is Direccão Nacional de Terras e Propriedades in Portuguese. Id.

302. Id.

303. New Computer Database, supra note 300.

304. Id. Approximately 5781 claims came from people in East Timor, and 6548 claims came from people in Indonesia. Xavier, supra note 75.

305. New Computer Database, supra note 300.

306. Id.

307. Timor-Leste land Law Program, Report on Research Findings and Policy ReCOMMENDATIONS For A LEgal FRAMEWORK FOR LAND DisPUTE MEDIATION (2004), http://www.jsmp.minihub.org/Traditional\%20Justice/Reports/LLP_Mediation\%20Report/LLP MediationReportEnglish.pdf [hereinafter A LEGAL FRAMEWORK]; see also USAID/East Timor, New Study Documents Land Dispute Mediation, (Apr. 9, 2004), http://timorleste.usaid.gov/EGHighlightsArchives/EGArchive9.htm [hereinafter New Study].

308. USAID/East Timor, Report Findings Help the Government Tackle Land Dispute Legislation, (May 5, 2004), http://timorleste.usaid.gov/EGHighlightsArchives/EGArchive 10.htm [hereinafter Report Findings Help].

309. New Study, supra note 307.

310. XAVIER, supra note 75.

311. Id.

312. See generally id. 
property until land ownership can be ascertained. ${ }^{313}$ The conditions for a lease agreement are: "[r]esidential use; [n]ational citizen; [p]roperty occupancy since 2000 ; [d] eveloped property; . . . automatic [m] onthly rent of US $\$ 10$ [sic] (ten American dollars); 1 year lease agreement," with automatic renewal for an additional year. ${ }^{314}$

In the future, East Timor anticipates restoring private property, but first must determine which land titles it will recognize. ${ }^{315}$ Furthermore, the East Timor government realizes that it needs to become a self-sufficient country: since "[d]uring the Indonesian occupation, East Timor was a dependent economy."316 This requires that East Timor restore its agricultural abilities; "for the past 3 decades the economy of East Timor has been structured in such a way so it has not been self-sufficient even in food." 317 The country is looking forward to the future and anticipating a time when it will no longer receive donor assistance. ${ }^{318}$ Senior economist Jose Garcia-Medrano stated that "donor assistance will be replaced in part by" oil and gas revenues. ${ }^{319}$

\section{RATIONALES FOR LAND REFORM IN EAST TIMOR}

Even though East Timor has implemented different programs and departments to begin resolving land claim conflicts, it is unclear if the methods the country is engaging in are long-term fixes or short-term solutions. " ${ }^{320}$ "Land reform is a long-term process" that might allow East Timor to reap long-term benefits. ${ }^{321}$ Although land reform has not been successful everywhere, it has had positive effects on the state of land tenure in many areas. ${ }^{322}$ Because East Timor land tenure systems are in a state of chaos, land reform might be the best

313. See id.

314. Id.

315. See generally FITZPATRICK, supra note 7, at 2.

316. Stephanie Fahey, The Future of East Timor: Threats and Opportunities for Economic Development of a Small Island State, UNIVERSIDADE NOVA DE LISBOA SYMP. ON E. TIMOR, INDON. AND THE REGION (2000), http://www.riap.usyd.edu.au/research/publications/ETimor.htm.

317. Id.

318. USAID/East Timor, Macroeconomics Policies Promote Economic Growth and Poverty Reduction, (Dec. 16, 2004), http://timorleste.usaid.gov/EGHighlightsArchives/EGArchive18.htm [hereinafter Macroeconomics Policies].

319. Id. Garcia-Medrano notes that East Timor faces the challenge of conserving its resources of gas and oil, so as to save the resource for future generations. Id. In 2000, East Timor signed an agreement with American, Japanese, and Australian oil companies. Gunn, supra note 22, at 239. Drilling was to begin in 2004. Id. This was the "largest investment ever made in East Timor" to date and provided a " $\$ 1.4$ billion investment in gas recycling." Id.

320. See, e.g., XAVIER, supra note 75.

321. LAND REFORM IN ZIMBABWE, supra note 166, at 188. "[It] is important that the work that we do in this field is not wasted in short term measures, and that we think clearly about leveraging the short term interventions we make into longer term impacts." LEWIS, supra note 59 , at 14.

322. See DEKKER, supra note 7, at 79, 103; see also id. at 88-102 (explaining land reform programs in various regions of the world). 
solution. $^{323}$

It is important to remember that land reform programs should be created specifically for a country in order to fit that country's unique needs. ${ }^{324}$ East Timor can learn plenty from other countries that have engaged in land reform. ${ }^{325}$ The failures experienced by Zimbabwe and South Africa can help to indicate the shortcomings of certain methodologies. ${ }^{326}$ Furthermore, the successes of these countries demonstrate what could potentially work well for East Timor. $^{327}$

Regardless of which country's methods East Timor chooses to study when ascertaining ways to resolve its land problems, it should consider land reform as a viable option. ${ }^{328}$ Moreover, the country needs to bear in mind that short-term fixes are not the best solution. ${ }^{329}$ An unstable land tenure system will continually inhibit the country from sustaining prosperous economic and social conditions because " nothing evokes deeper passions or gives rise to more bloodshed than do disagreements about territory, boundaries, or access to land resources.",330

\section{A. The Ways East Timor Could Benefit from Land Reform}

The benefits that East Timor could reap from land reform are plentiful. ${ }^{331}$ On the most basic level, land reform could serve "to resolve the overlapping and competing tenure rights of people" by redistributing the land. ${ }^{332}$ Thus, East Timor's dilemma of ascertaining what land title claim to recognize could be solved by land reform. ${ }^{333}$

A redistribution of the country's land would provide property ownership to a large number of peasants who are currently illegally possessing land. ${ }^{334}$ Redistribution could also result in a more equal distribution of land. ${ }^{335}$ This would likely prevent militia and rebel upheaval in the future; evidence indicates that militia violence often occurs because of inequality of land ownership or

323. See generally FITZPATRICK, supra note 7. Contra FITZPATRICK, supra note 12 (finding that the creation of a new system of land tenure may not be the best option).

324. See generally DEKKER, supra note 7, at 78 .

325. See id. at 88-102 for a discussion of land reform programs implemented in other countries.

326. See generally Sihlongonyane, supra note 210.

327. See supra $\mathrm{pp} .23-43$.

328. Contra FITZPATRICK, supra note 12 (discussing the disadvantages of land reform).

329. See LEWIS, supra note 59, at 14.

330. Id. at 5. "Post-conflict experiences regularly demonstrate that land and property issues can provoke secondary conflicts." Id.

331. See supra note 154 and accompanying text.

332. Lungisile NTSEBEZA, LAND TENURE REForm, TRADITIONAL AUTHORITIES AND RURAL LOCAL GOVERNMENT IN POST-APARTHEID SOUTH AFRICA: CASE STUDIES From THE EASTERN CAPE 39 (1999).

333. See id.

334. See id.

335. DEKKER, supra note 7 , at 77. 
lack of access to land. ${ }^{336}$ Additionally, a redistribution of land would enable the country to make good use of abandoned land. ${ }^{337}$

Economically, land reform could help the country become more selfsufficient. $^{338}$ Traditionally, East Timor has been an agricultural country, ${ }^{339}$ however, it failed to meet its agricultural potential during the Indonesian occupation. $^{340}$ The country must start harvesting more crops, not only to provide food for East Timorese, but also to potentially export to other countries. ${ }^{341}$ For example, coffee is East Timor's "main potential export crop . . . [but] coffee trees have not been adequately cared for over the past 20 years."342 Approximately 20,000 of East Timor's 30,000 hectares of coffee plantations were "taken over by the Indonesian government" or were put in the hands of large companies. ${ }^{343}$ The lack of certainty surrounding land titles has had a momentous effect on East Timor's prominent export product. ${ }^{344}$

Additionally, "East Timor has the capacity and experience to produce livestock for export." ${ }^{345}$ Studies demonstrate that people with certainty of land title use the land more efficiently. ${ }^{346}$ By redistributing the land, placing individuals on property, and granting these individuals legal title to property, the country's agricultural strength might be restored. ${ }^{347}$ East Timor's economy will also benefit from foreign investment; ${ }^{348}$ however, foreign investors do not want to enter a country where land title is uncertain. ${ }^{349}$ Land reform can provide this certainty. ${ }^{350}$

There are numerous benefits that can derive from land reform. ${ }^{351}$ First, it is important to understand the needs of the country when creating a land reform program. $^{352}$ Specifically, East Timor has a large amount of communal land, ${ }^{353}$ so the country must be sensitive in attempting to title this land. ${ }^{354}$ The

336. See, e.g., LAND REFORM IN ZIMBABWE, supra note 166, at 8.

337. FITZPATRICK, supra note 12.

338. See, e.g., Gunn, supra note 22 , at 238.

339. Fahey, supra note 316; see also Gunn, supra note 22, at 238 (noting there is an "untapped potential in the agricultural sector").

340. See LEWIS, supra note 59, at 9.

341. Gunn, supra note 22, at 237-38.

342. Fahey, supra note 316.

343. Gunn, supra note 22, at 238.

344. Id. Id.

345. Id. East Timor has a "vast southern rangeland" that is ideal for producing livestock.

346. See FITZPATRICK, supra note 7, at 169.

347. See id. at 169-70.

348. Id.

349. See supra note 139 and accompanying text.

350. See NTSEBEZA, supra note 332 , at 39 .

351. See DEKKER, supra note 7, at 103, for a discussion of "[i]mpressive land reforms [that] were carried out in Japan, Taiwan, South Korea, Egypt, Iraq, and Israel."

352. Id. at 80 .

353. FITZPATRICK, supra note 7 , at 167.

354. See generally id. (discussing the different land titles that East Timor could recognize). 
successes and failures of other countries' land reform programs can help provide information as to how land reformation should be accomplished.

\section{B. Lessons Learned from South Africa}

A major problem in South Africa's land reform program was a lack of connectivity with other departments in the government. ${ }^{355}$ This demonstrates the need to weave a land reform program into different governmental departments and agencies. ${ }^{356}$ To avoid the problem encountered by South Africa, East Timor should take active measures to ensure that the Directorate of Land and Property (DNTP) remains closely associated with other departments in the government. ${ }^{357}$

Additionally, the land reform program could require departments other than the DNTP to perform certain functions or duties relating to land reform. ${ }^{358}$ Ultimately, this would ensure that the land problems facing the country do not disappear from the country's agenda. ${ }^{359}$ To date, it appears that resolving land issues has been an important task for East Timor officials; they have continually sought out new laws and organizations to help resolve these problems. ${ }^{360}$ Still, measures should be taken to ensure that the land tenure system remains of utmost importance.

South Africa's land reform program failed to take into account poverty, food shortage, and unemployment. ${ }^{361}$ Instead, the country focused solely on resettling families with no concern for how these families would survive once on the land. ${ }^{362}$ East Timor can learn from this deficiency within the South African land reform program. To prevent people from obtaining property without proper funding to build a house or work the land, money from foreign donors could be loaned to new land owners through a loan system using the "land as collateral." 363 In addition, programs could be implemented to teach new landowners, specifically new farmers, how to use their land productively and in ways that do not ruin the land. ${ }^{364}$ By providing this service to new landowners, food shortages could be prevented, ultimately helping the economy and decreasing poverty in East Timor. ${ }^{365}$

As a whole, the land reform system in South Africa did not consider the

355. Sihlongonyane, supra note 210 , at 151 .

356. See id.

357. See generally supra p. 27 (explaining South Africa's problems with government departments not remaining connected with one another).

358. See, e.g., Sihlongonyane, supra note 210 , at 151.

359. See generally id.

360. See XAVIER, supra note 75.

361. Sihlongonyane, supra note 210 , at 151 . Zimbabwe also experienced this problem. LAND REFORM IN ZIMBABWE, supra note 166, at 187-88.

362. Sihlongonyane, supra note 210 , at 151 .

363. DEKKER, supra note 7 , at 81 (making this suggestion).

364. Id. at 81; see also LAND REFORM IN ZIMBABWE, supra note 166, at 127.

365. See DEKKER, supra note 7, at 81 . 
needs of its people. ${ }^{366}$ Instead, it attempted to apply one uniform method across the entire region. ${ }^{367}$ Certain areas often may require specific, individualized methods to solve land disputes, be it through negotiation, mediation, or land seizure. ${ }^{368}$ The failure to employ the correct method can result in a tense environment; ${ }^{369}$ evidence exists that indicates East Timor is cognizant of this problem. ${ }^{370}$ In February 2004, the Timor-Leste Land Law Program released an extensive report on different policies to handle land disputes. ${ }^{371}$ The research considered the culture, subjects, and geographic nature of many different regions in the country when suggesting methods to mediate land disputes. ${ }^{372}$

Overall, it looks as if East Timor has already taken into account many issues that South Africa failed to address. ${ }^{373}$ It is important, however, for East Timor to continue its efforts. Additionally, if the country were to create a land reform program, it would be important for it to integrate its current efforts into the program.

\section{Lessons Learned from Zimbabwe}

Zimbabwe's land reform program has been widely criticized because it takes a "top-down, directive, controlling approach which assumes that officials know best and that peasants and pastoralists need to be told what is best for them." 374 Thus, it has been suggested that consultations should take place prior to the commencement of a land reform program. Such consultations should take place with the "commercial farmers, the landless, traditional chiefs, prospective farmers, financial institutions, farmers' union and industry." Consultations would enable more people to have a voice and give the government a better idea of the interests of everyone involved. ${ }^{376}$

Zimbabwean surveys indicate the methods and procedures of land selection were unfairly discriminatory. ${ }^{377}$ Many argue that political allies of Prime Minister Mugabe have been the primary beneficiaries. ${ }^{378}$ East Timor could avoid this problem by implementing an impartial lottery system or some other methodology, which does not give preference to the elite and political

366. Sihlongonyane, supra note 210 , at 159.

367. Id.

368. Id.

369. DEKKER, supra note 7, at 102-07.

370. See, e.g., XAVIER, supra note 75.

371. A LEGAL FRAMEWORK, supra note 307. The research for this report was funded by USAID. Id.

372. Id.

373. See generally Xavier, supra note 75 (providing new laws and polices implemented by East Timor).

374. Palmer, supra note 293 , at 5.

375. SITHOLE \& RUSWA, supra note 179 , at 30.

376. See generally id.

377. See generally id.

378. Id. at 10. 
allies of those in power. ${ }^{379}$

Zimbabwe made a major mistake at the outset of its land reform program. ${ }^{380}$ The Zimbabwe government set unrealistic goals; the "targets were virtually plucked from the air with little account of the practicality thereof."381 The unrealistic targets came back "to haunt the Zimbabwean government." ${ }^{382}$ It appeared as if Zimbabwe was accomplishing very little because the results never matched the goals. ${ }^{383}$ Therefore, it is important to carefully study a country's potential before making announcements of projected targets. ${ }^{384}$

Many people criticized Zimbabwe's efforts to boost its economy by placing restrictions and requirements on resettled lands. ${ }^{385}$ Such requirements were often placed on new landowners to produce certain products and to refrain from certain uses of the land, and leases were contingent upon adherence to these requirements. ${ }^{386}$ The new landowners felt they should not have had to grow specified products for public market. ${ }^{387}$ In addition, many disliked that land was only leased and not sold outright. ${ }^{388}$ These lessees thought it was unfair to place contingencies on their ability to remain on the land. ${ }^{389}$ Zimbabwe's preferred reasons for placing restrictions and requirements on resettled land was to avoid an "economic and environmental disaster" that many critics of the land reform program predicted would occur. ${ }^{390}$

East Timor could avoid these criticisms by restricting the use of land for the first year or two of occupancy and thereafter allow individuals to grow products of their choice. ${ }^{391}$ During this initial period, ownership could be contingent upon following restrictions and requirements, but after the initial period complete ownership could vest in those occupying the land. By employing this type of system, the government could monitor the economy for a period of time, while still providing individuals the freedom to produce products of their choice. These suggestions should be considered by East Timor when determining the best way to address these issues. ${ }^{392}$

Some ideological arguments regarding land reform in Zimbabwe center

379. See generally id.

380. See DE VILLIERS, supra note 238, at 11.

381. Id.

382. Id.

383. Id. South Africa was cognizant of this idea and carefully assessed its land reform programs' abilities before announcing outrageous goals. See id. at 81 .

384. See id. at 81.

385. LAND REFORM IN ZIMBABWE, supra note 166, at 127-28.

386. Id. at 128. See also RICHARDSON, supra note 79 , at 145 (finding that when the government owns land and merely leases it, people "are vulnerable to non-renewal at any time").

387. See LAND REFORM IN ZIMBABWE, supra note 166 , at 127-28.

388. Id. at 128 .

389. Id.

390. Id. at 127.

391. See, e.g., id. at 126.

392. See generally id. 
on the idea "that private property is a near-sacred right" and should not be taken away from landowners to redistribute to landless individuals. ${ }^{393}$ The main counterargument to this position is that private property is considered "the status of foundation of a just and civilized society. "394 To hold this promise means to accept "that private property cannot perform this noble function if most people are without it!",395

Both Zimbabwe and South Africa were able to "mobilize funds from donors, philanthropists and other well wishers, and ultimately from the local financial market." ${ }^{, 366}$ This will likely aid them in buying land and providing various programs. $^{397}$ The success of any land reform program is dependant upon a country's ability to finance it with the help of donors. ${ }^{398}$ Thus, if possible it would also be extremely advantageous for East Timor to obtain financial assistance from donors before implementing land reform.

\section{CONCLUSION}

Currently, East Timor's land tenure system is in a state of chaos with conflicting land titles, squatters, large amounts of abandoned property, and massive destruction of homes and infrastructure. There are presently four different types of land claims being brought, and the country is faced with the difficult task of determining which titles to recognize. While all four land claims have a basis for recognition under certain legal principles, not all claims should be recognized for a different set of equitable reasons. Choosing any one type of land claim could result in a magnitude of difficulties.

East Timor has begun to study its land problems and execute new land laws, but it still has a long and difficult road ahead. Many of the purported solutions currently being implemented might only have short-term beneficial effects. Land reform may be the best option for the country, but East Timor must remember that "[l]and reform is a long-term process, not an event." "399 Reforming the land system could greatly help the country's economy, as well as lead to a more equitable redistribution of land. There is, however, no set method or program for reforming land that can be adopted. Instead East Timor must develop a program that specifically fits the needs of its people. ${ }^{400}$

393. Id. at 188 .

394. Id.

395. Id.

396. Id at 191-92.

397. See id.

398. See id.

399. Id at 188

400. "The challenge for East Timor is to recapture its own identity allowing for the judicious absorption of remnants of the Portuguese and Indonesian administrations in the form of language, religion and other behavioural codes." Fahey, supra note 316. 
